\title{
AN EASTERN TRADITION IN LULLIAN BLAQUERNA: THE HOLY FOOL RAMON LO FOLL ${ }^{1}$
}

\section{Jordi Redondo}

GIRLC, Universitat de València, Departament de Filologia Clàssica, Facultat de Filologia, Traducció i Comunicació. Blasco Ibáñez 32, 46010 València, País Valencià, Spain; jordir@mail.ru

The paper analyzes a passage from the novel Blaquerna written by Ramon Llull from approximately 1276 to 1283 . It has not till now received a coherent explanation able to give an account of its literary models. A comparative study shows how Llull treats a theme borrowed from both the Classical and the Christian tradition. The Classical tradition depends mostly on the image of a philosopher, especially one of the Cynical school, blended with the character of Aesop. In the Middle Ages, the theme achieved its final shape through the addition of content and stylistic elements borrowed from Christianity. The closest source available to Llull could be the Life of Symeon of Leontius of Cyprus, an important work as regards the diffusion of the character displayed in the text under consideration.

Keywords: Ramon Llull, Byzantine tradition, madness, holiness, cynicism.

\section{Ramon Llull, his literary work and the novel Blaquerna}

The mystic Ramon Llull, recognized as blessed by the Catholic Church, and as martyr by the Franciscan Order, was born on $25^{\text {th }}$ January 1235 in Palma, the capital of the Kingdom of Majorca, just six years after the Christian Conquest. His family obtained several possessions and settled in the city as it became the court of King James I. Because of the education received as a royal page, Llull knew all about the poetic tradition of the troubadours, and as a young man he also displayed licentious habits. In spite of being married to a noble lady who bore him two children, Llull did not stop living his mundane life, till he experienced some kind of trouble and became a servant of Christ. In the course of his new life, Llull created extended philosophical and literary works, as he is believed to have written nearly five hundred treatises. ${ }^{2}$ His background includes the knowledge of the Arabic language, and his formative years and his trips to Italy, France, Egypt, Cyprus and other countries made him able to obtain a panoramic vision which is also reflected in his literary production.

The novel Blaquerna (Llibre d'Evast e d'Aloma e de Blaquerna son fill $^{3}$ ) has been reputed as one of the most interesting texts of the Catalan medieval literature. It deserves a prominent place both from the point of view of literary creation and from other perspectives, as religious and ideological in general, ethical, and epistemological. Important questions concerning the novel are still being debated (first of all, the problem

1 Thanks are due to the anonymous reviewers for their valuable suggestions and emendations. We thank also Sahra Abdulle (Universitat de València) for her revision of the English version of this paper.

${ }^{2}$ Nearly a half of this production has been considered spurious. Its main subjects are alchemy and esoterical science.

${ }^{3}$ Besides the Renaissance editio prínceps (Bonllavi, 1521) there are several modern editions: Galmés, 1935-1954; Gallofré, 1982; Soler, Santanach, 2009. The last edition makes its choice in favour of the spelling Blaquerna, which is attested in the oldest manuscripts, being from the fourteenth century onwards substituted for the form Blanquerna (Tarré 1941; Platzeck 1980). Translations into English, French (four different translations), Latin, Romanian, Spanish and Swedish have been published.

(C) St. Petersburg State University, 2017 
of its chronology: Baist 1879; Cramer von Bessel 1935; Oliver 1985; Ripoll 2012). The literary models of the novel have not till now become the object of an accurate study (Brummer 1979; Schleicher 1958, 48-49), and the same can be said about its reception (Brummer 1986). As regards the models, it should be taken into account that Barlaam and Josafat has been recognized as such (Badia 1992, 97-119; González Casanovas 1992, 157 192; González Casanovas 1993). The structure of the novel can be defined as a complex one, since two other independent texts are embedded therein, the short novels Llibre d'amic e amat and Llibre de contemplació - that is to say, Book of Lover and Beloved and Book of contemplation. On the date of the text, Brummer suggests a period before 1283, when Llull was in Montpellier (Brummer 1958; the date is accepted by Bonner 1986; see also Garcías Palou 1957; Schleicher 1959; Oliver 1959; Tusquets 1976). On the literary models chosen, Brummer himself approves the Queste du Saint Graal and discards the Hayi ibn Yaqzan d'Ibn Tufayl, formerly suggested by Vossler and Platzeck (Vossler 1950, 308-309 and 369; Platzeck 1964, 7, n. 15).

Our aim is to show that Llull was indebted not only to the Western (including the western Arabic) literary tradition, but also to the Eastern one. As a marker of the relationship between the literary work of Ramon Llull and the Eastern literature we will at first consider the character of Ramon lo Foll.

\section{Ramon lo Foll in Blaquerna}

To begin with, chapter LXXIX of Blaquerna formally follows the pattern of an apologue where the protagonist, a sage and pious monk, becomes now the Pope and displays his huge wisdom. But there is another character who attracts attention when he admonishes the Pope with an extraordinary example:

Esdevenc-se un dia que l'apostoli convidà tots los cardenals, e tenc gran cort aquell dia. Quan hagren menjat en la cort, vénc un home vestit com a foll e hac ras son cap, e en sa mà portà un esparver e en l'altra mà tenc una corda on era lligat un ca que menava. Saludà lo senyor apostoli e los cardenals e tota la cort de part lo senyor emperador, e dix aquestes paraules: -Jo son Ramon lo Foll, qui venc per manament de l'emperador en esta cort per usar de mon mester e per cercar mos companyons. Quan hac dites aquestes paraules, ell donà a picar a l'esparver e puix féu-lo venir a son puny dues o tres vegades. Aprés ferí e baté l'esparver amb la corda d'on era lligat son ca, e altra vegada cridà l'esparver que vengués a son puny. E l'esparver, per ço car lo foll l'havia esquivat e l'havia ferit, fugí e volà fora lo palau on l'apostoli era, e esdevenc salvatge. Quan Ramon lo Foll hac perdut son esparver, ell ferí molt fortment lo ca dues o tres vegades, e tota hora que l'apellava, volenterosament lo ca tornava a ell. -Ramon lo Foll-dix l'apostoli-, qual és ton estament? Ni per què dius que en esta cort est vengut cercar tos companyons? Ni què significa ço que has fet de l'esparver e del ca denant nosaltres? -Sènyer -dix Ramon lo Foll-, jo era cosí en la cort de l’emperador e depenyia'm foll per ajustar diners. E l'emperador ha'm tant dit de la passió de Jesucrist e de la noblesa de Déu, que vull ésser foll per donar d'ell honrament e honor. E no vull haver manera a mes paraules per força de gran amor. E per ço car vostra cort ha major honor per la passió de mon amat e per l'encarnació que nulla altra cort, cuit atrobar en vostra cort molts companyons qui sien de mon ofici. L'esparver significa los hòmens qui no ajuden a home ni a sostener honrament e l'ordenament de vostra cort sens diners e serviis; e quan hom los prega e no els dóna res, fér hom llur coratge de peresa e treball, e per açò són a home estranys e salvatges. Lo ca significa los hòmens qui són tan aflamats e tan ajustats d'amor, amb l'honrament e l'ordenament de la cort per ço que Déus hi sia honrat, que, sens que hom no satisfaça a llurs treballs, sostenen treballs e afanys per home qui haja a procurar alcunes coses en cort, e són 
als hòmens plaents e agradables. Com Ramon lo Foll hac usat de son ofici e hac respost a l'apostoli, lo Joglar de Valor cantà e sonà estruments molt dolçament a honor de valor.

"It came to pass one day that the Pope invited all the Cardinals to visit him, and held a great Court on that day. When they had eaten, there came into the Court a man with shaven head and clothed in the garb of a fool. In the one hand, he carried a sparrowhawk, and in the other hand a cord to the which was tied a dog which he led. This man greeted the Pope and the cardinals and the whole Court on behalf of the Emperor and spake these words: 'I am Ramon the Fool, and come into this Court by order of the Emperor to make use of my office and to seek for my companions. When he had spoken these words, he struck the sparrowhawk and afterwards made it come to his hand two or three times. After this he struck and beat the sparrowhawk with the cord to the which the dog was tied, and again he cried to it that it should come to his hand; but the sparrowhawk, because the Fool had struck it, escaped and flew out of the palace of the Pope, and became wild. When Ramon the Fool had lost his sparrowhawk, he struck the dog very severely two or three times; and whensoever he called it the dog returned willingly to him. 'Ramon the Fool!' said the Pope, 'Who art thou and wherefore sayest thou that thou hast come to this Court to seek thy companions? And what is the significance of that which you hast done in our presence with the sparrowhawk and with the dog?' 'Lord!', said Ramon the Fool, 'I was aforetime in the Court of the Emperor, and I learned to be a fool, to the end that I might gather together money; and the Emperor has spoken to me so often of the Passion of Jesus Christ and of the nobility of God, that I desire to be a fool that I may give honour and glory to Him, and I will have no art nor device in my words by reason of the greatness of my love. And since thy Court has greater honour than any Court besides, by reason of the Passion of my Beloved and of His Incarnation, therefore do I think to find in thy Court many companions who are of my office. The sparrowhawk signifies the men who assist not to sustain the honour and governance of thy Court without money and rewards; and when a man prays them naught they become disheartened, afflicted and slothful; therefore, they escape from among men and become wild. The dog signifies those men that are so greatly inflamed and kindled with love for the honour and governance of thy Court in such a way that God can be honoured there, that without any reward for their endeavour they assume these trials and anxieties by reason of men that desire to gain advancement in the Court, and they are pleasing to all men and agreeable. When Ramon the Fool had thus exercised is office, and had answered the Pope, the Jester of Valour sang and played instruments of music very sweetly in honour of Valour" (Allison Peers 1926, 317-319).

The character of Ramon the Fool did not deserve an accurate study from any researcher, although Schleicher underlined the symbolism of this person (Schleicher 1958, 119). Therefore, beyond some inconsistent and occasional remarks there has not been any contribution intended to evaluate from the literary point of view and by means of philological research the origin, features and functions of Ramon. This is the scope of our study.

The thematic components of the passage are the following: 1) the main character, Ramon the Fool, appears dressed as a crazy man, that is to say, he is described as someone clumsy, unaware of the habits which are usual between persons of a distinguished condition; 2) the short prosopopoia of the character includes a second trait, the indication that his head is shaven; 3 ) besides the particular traits of such an exceptional character, the situation is also quite peculiar, since he arrives by order of the emperor, so that he would have been perceived as an ambassador, or at least a high dignitary; 4) the purposes of this ambassador are 'to make use of my office and to seek my companions'; and 5) by his own confession this man tells us: 'I was aforetime in the Court of the Emperor', that is to say, he was put under the imperial protection to receive from him a courteous education; he came 
from a noble family, although by his initiative he took the office of a jester who was playing the fool: 'and I learned to be a fool, to the end that I might gather together money'. Therefore, our author has introduced to the scene a character that is placed in power bordering on rebellion, for with his aspect plainly ambiguous he subverts the limits of habits and strict courteous rules.

With great probability we can consider the character of Ramon the Fool as a literary self-portrait of the author. ${ }^{4}$ Like him, Llull was a young man of noble, but modest origin, for he was a member of a Barcelonese family from the ranks of the lower nobility. ${ }^{5}$ As Ramon the Fool, Llull was admitted to a royal court, that of James II of Mallorca, where he performed some positions of trust. ${ }^{6}$ On the other side, the description of Ramon lo Foll as a courtesan has an interesting literary parallel in the tale LXIV, 'D'una novella ch'avenne in Provenza allà corte del Po', from the Italian Novellino:

In quello giorno ordinaro la festa, e poneasi uno sparviere di muda in su uniasta. Or venia chi si sentia si poderoso diavere e di coraggio, e levavasi il detto sparviere in pugno. Convenia che quel cotale fornisse la corte in quello anno (Tosi 1825, 86-87).

"On that day they arranged a celebration, and each of them put a sparrowhawk on a spear. Therefore, there arrived people who felt quite proud of his wealth and his courage, and who led the sparrowhawk in hand. It was suitable for such a man to provide the court this year".

Therefore, the emergence of our character on the spot puts in front of our eyes a strong contrast between two images, that of the marginal person who arrives to the seat of power - the papal court - with shaven head, and that of the man who takes part in courteous performances and even becomes the main protagonist of them.

\section{The literary and religious tradition of the holy fool.}

The character under consideration follows all the suitable patterns for the so-called

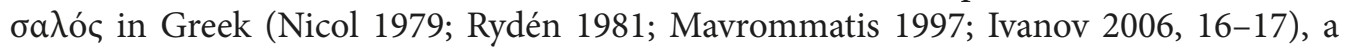
holy fool in English and fou de Dieu in French (see on this matter Swain 1932; Screech 1980; van Esbroek 1999; Spidlik 1964; Vandenbroucke 1964; Cameron 1979; Rocheau 1980; Feuerstein 2006), as well as majdhub in the Islamic culture (Bausani, 1958; Dols, 1992 and 1987), being an especially well-known character in Russian spirituality, where they are called юродивые [iurodivyie] (Pope 1980; Ivanov 1999; Rudi 2007; Hunt 2011). ${ }^{7}$ The features of a holy fool are, first of all, his loneliness, that links him with every kind of marginal individual; second, the use of parables as a strategy for communication; third,

4 The point has been already recognized: El personaje de Ramon el Loco (Ramon lo Foll), de evidente proyección autobiogràfica etc. (Aragüés Aldaz 2016, 104). Ramon lo Foll represents the personal transformation of the author, formerly engaged in courtisan life and now devoted to religious purposes (Badia, Santanach, Soler 2016, 106; contra: Friedlein 2011, 178, n. 3).

${ }^{5}$ See on this family Hillgarth 2001, 21, about a grant of lands - just a small territory in any case dated on July 1, 1232, whose beneficiary was a certain R. Llull, allegedly the father of our author. See also Pérez, Miralles, 1971.

${ }^{6}$ Brummer quotes passages from the Vida coetania in support of the view that the author was given, in his own words, a corteous and chivalrous education (Brummer 1979, 2).

7 According to Ivanov, a difference must be considered between iurodivye and stastoterptsi, for these last in their human life could even have been cruel and unscrupulous chieftains, whose violent death, however, was assumed with an exemplary dignity, making of them martyrs and models of conduct (Ivanov 2006). 
the ability to speak in those true words that other people do not wish to say because of fear and shame; fourth, a holy fool taps on divine inspiration as his source of knowledge and, what is more, of authority. Till now, it could be said that nothing distinguishes a holy fool from a prophet; but there are three more features that gradually make a difference: a certain closeness to power, but exempt of any attempt to share a free life of those mighty people who can decide for all; the contempt for wealth and earthly pleasures; and, last but maybe the most important, craziness, be it real or simulated ${ }^{8}$.

The origin of this so well-defined archetype has often been linked to some religious traditions, among which the Hebrew has largely attracted the attention of scholars (Kobets 2008). Nevertheless, we will follow a different methodological pattern which fits our claim on the main role of the Classical tradition in the establishment of the Medieval and Modern literatures. In the late Classical Age, one of the elements that constituted a link between the Ancient and the Medieval cultures was the tendency for people to sacralize some extraordinary individuals (Brown 1971; Cameron 1999). Actually, the character is even much older, since it is fully indebted to the heritage of the $\theta \varepsilon \tilde{o} o$ ä $v \delta \rho \varepsilon \varsigma$ represented by philosophers (Bieler 1935-1936; Brown 1971; Talbert 1978; Fowden 1982; Cox 1983; Blackburn 1991; Grau 2013).

From this perspective, the portrait of a Cynic philosopher has been the most productive in creating the character of a holy fool. Our Classical sources reflect the merger, already established and being at work, of both characters, the Cynic philosopher and the Christian saint. In his Isthmic Oration, probably dated in 156 A. D., Aelius Aristides

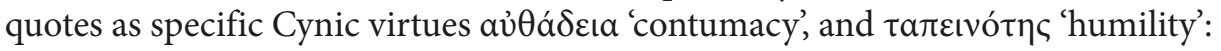

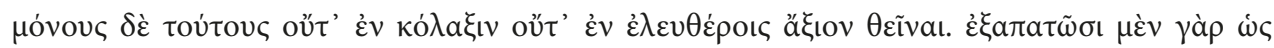

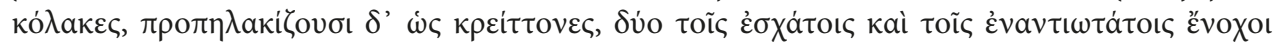

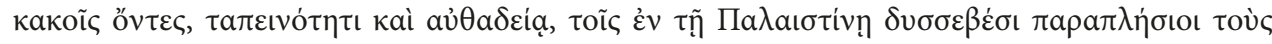
тро́тоич.

'Only these people are not worthy to be ranged among flatterers and among free individuals: they trick like flatterers, but they taunt like the most mighty people, for they are guilty of two extreme and completely opposite crimes, contumacy and humility, as they are by their habits quite similar to the Palestine impious' (Ael. XLVI 309, 9-11, my translation)

Towards the beginning of the third century, the Refutation of All Heresies, usually attributed to Hippolytus, praised Tatianus because of his very widespread and known

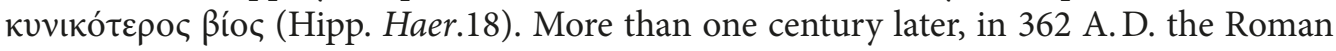
emperor Julian showed the similarity of Cynics and Christians once again (Iul. Or. 7, 22b). Later on, in the fifth and sixth centuries, the Neoplatonic philosophers renewed the interest in the Cynic school, from which they have borrowed some concepts linked to the mystical quest of truth and goodness. Theologians and ascetics supporters of monachism were involved in this quest, as well as many pagan philosophers (Downing 1982; Pépin 1982; Kinney 1996).

The interest in Cynism arrived even to the mystical Hebrew tradition: towards the middle of the third century it borrowed from the Cynic authors not only several elements

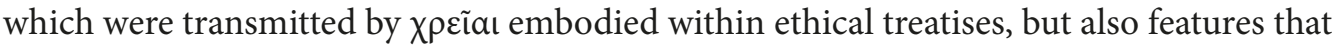

8 This was their main feature according to Benz, Nigg and Hauptmann (Benz 1938, 1-55; Nigg 1956; Hauptmann 1959). 
were usual in the Cynic ethopoiiai, for example sleeping on a grave, squandering every kind of wealth and wearing clothes that only the socially marginalized do. ${ }^{9}$

Another possible model for the holy fool is that of Aesop, the wiseman who had admonished so many cities and shown himself, however, as a completely crazy man (Aesopi vita 130). As a 'crazy wiseman' Aesop reproduced personal habits and situations that had formerly been personalized in the character of the Cynic Diogenes, including the famous scene in which he was looking for a man, lamp in hand. ${ }^{10}$ The immense popularity of the Aesopic fable was instrumental to the fact that the literary character to which the whole genre was attributed, became also known in many other cultural traditions. ${ }^{11}$ As an inseparable part of the same religious tradition, the Russian phenomenon of the so-called юродивые [iurodivyie] is marked by two specific traits: an honour of holiness is bestowed on them, and they fulfil a role of intercessors in achieving the glory of paradise.

\section{The reception of the tradition of the holy fool in Llull}

One of the main links, maybe the most important, between the tradition of the ancient philosophical schools, especially the Cynic one, and Christian hagiography was The Life of Symeon the Fool written by Leontius of Cyprus, bishop of Neapolis, the present Limassol. Leontius tells how Symeon the fool, a historic character quite well known, ${ }^{12}$ used to take his walks leading a dead dog (Rydén 1963, 145; all our quotations are taken from this edition) and used to relieve his physical needs just in the street (Rydén 1963, 48). In a keen study, Krueger has dealt with analogies between the Cynic philosophers in general (Diogenes in particular) and Symeon the Fool, ${ }^{13}$ and he concludes that the latter was a conscious imitator of the provocative habits of his Athenian predecessor. ${ }^{14}$ Symeon personified in a perfect way the idea of rebel holiness, able to cause immediate reactions by means of mixing surprise, paradox and contrast (Sirkin 1982; Dagron 1990). The huge attention paid to this archetype in Byzantine literature is far beyond any doubt. Although in the Orthodox Christendom itself the holy fools went into decline till they nearly completely vanished towards the ninth century, because of the will of the Church to control every manifestation of faith, the Life of Symeon the Fool was widely diffused in Eastern as well as in Western Europe; in the Eastern Christendom it contributed to a large degree - as it was also done by a parallel text, the Life of St. Andrew the Foolto the spread of an ideal of holiness that became rooted, even if partially modified, in

${ }^{9}$ On the character of Diogenes of Sinope, see López Cruces (López Cruces 2015). On the reception of the Cynic philosopher, cf. Luz (Luz 1989).

${ }_{10}$ On the relation of Aesopus to the Cynic school, and especially to Diogenes, see Zeitz, Jedrkiewicz, and Kurke (Zeitz 1935, 230-233; Jedrkiewicz 1989, and 1990-1992; Kurke 2001, 7-10).

11 On the reception of elements borrowed to the dramatic tradition - the Aesopic fable is particularly indebted to comedy, - see Fuertes (Fuertes 2012, 101).

12 There is a lonely voice against the authenticity of this character (Magdalino 1999, 85).

13 We know that Diogenes of Sinope was the model for the literary character of Symeon (Krueger 1996, 72-107), and that the Cynic school was the generic model for this type of Christian saint (Krueger 1996, 126-128); see also Rocheau and Largier (Rocheau 1978; Largier, 1997, 375-377).

14 'The parallels between Symeon and Diogenes are striking. Leontius carefully models Symeon's behavior on that attributed to this Cynic philosopher in both pagan and Christian lore' (Krueger 1996, 73). A recent contribution argues that Cynicism and monachism should be considered as two parallel phaenomena, but without any noteworthy influence of the first on the second, a theory that does not seem satisfactory (Goulet-Cazé 2014). 
the context of the Slavic religiosity (Challys, Dewey, 1977). Thus, in the tenth century we find, among the last attestations of the character, the Life of St. Andrew the Fool, by Nikephoros of Constantinople, which is yet no more than a fictionalised character, certainly very influential for the spread of the topic, especially in Eastern Europe. As for Western Europe, the arrival of the prosopography of a holy fool could have been faded or was even stopped by the old-established opposition between the religious forms of the ancient Eastern and Western Roman Empire (Brown 1982). However, the interest for such a character, so innovative and fascinating, prevailed over the intellectual and moral prejudices, so that there are many cases of its reception in Western Europe (Ivanov 2006, 376-382). The close imitation of the character was put into practice in the fifth century by Kentigern of Scotland - known in Glasgow as Saint Mungo, the founder of the city, - in the eighth century by the bishop Aldhelm of Sherborne, and by other saintly Irishmen (Gougaud 1921; Reynolds 1968). It is highly probable that the Life of Symeon the Fool, so reputed as it was in Eastern Europe, attracted the attention of Western scholars like Llull. It should be mentioned that Llull was a franciscan friar, and that the founder of this order has been considered close to the status of a holy fool himself.

If we now look at our passage from Blaquerna, it is quite easy to see there, in spite of the shortness of the presentation of Ramon lo Foll, that the author was clearly inspired by the character of a holy fool, and especially by both the prosopopoiia and the ethopoiia of Symeon the fool. First of all, from the very first sentence on the arrival of Ramon we are told that e en l'altra mà tenc una corda on era lligat un ca que menava and in the other hand a cord to the which was tied a dog which he led. This image obviously reminds of the following passage of the Life of Symeon the Fool:

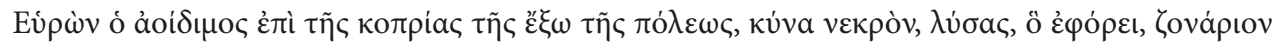

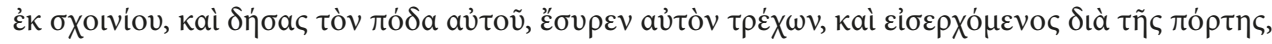

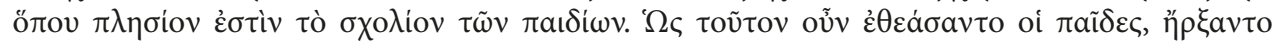

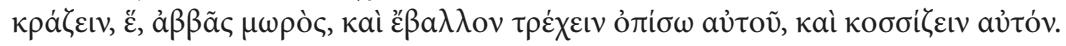

"'When the famous Symeon found a dead dog on a dunghill outside the city, he loosened the rope belt he was wearing, and tied it to the dog's foot. He dragged the dog as he ran and entered the gate, where there was a children's school nearby. When the children saw him, they began to cry, 'Hey, a crazy abba!' And they set out to run after him and box him on the ears'” (Rydén 1963, 145; translation taken from Krueger 1996).

The defiant and provocative behavior of Ramon lo Foll is perfectly shown from the very beginning, but Llull does not restrict his presentation to the sentence vénc un home vestit com a foll e hac ras son cap there came into the Court a man with shaven head and clothed in the garb of a fool. The Life of Symeon the Fool, however, depicts a complete ritual of transgression (see on this topic Ivanov 1995, 439-445) which is lead so far as it is possible within the context of the Christian tradition:

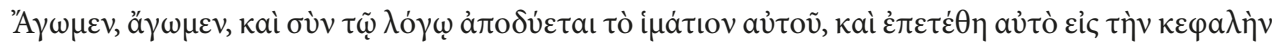

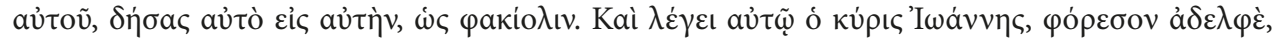

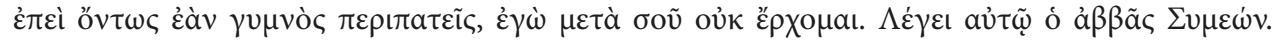

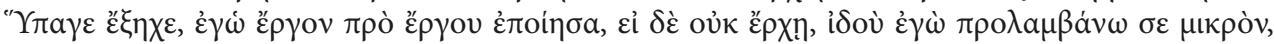

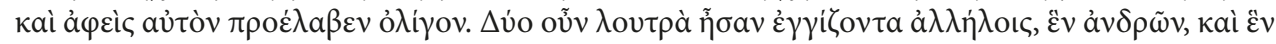

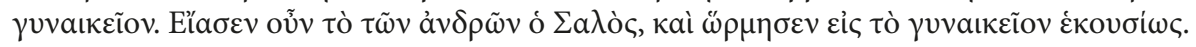


“'Yes, let's go, let's go!' And with these words, he stripped off his garnment and placed it on his head, wrapping it around like a turban. And Deacon John said to him, 'Put it back on, brother, for truly if you are going to walk around naked, I won't go with you'. Abba Simeon said to him, 'Go away, idiot, I'm all ready. If you don't come, see, I'll go a little ahead of you'. And leaving him, he kept a little ahead. However, there were two baths next to each other, one for men and one for women. The Fool ignored the men's and rushed willingly into the women's'" (Rydén 1963, 150).

The third passage of the Life of Symeon the Fool has also a clearcut reflex in Llull's presentation of Ramon, who is depicted as 'a man with shaven head' (e hac ras son cap) arriving to the Court. The text of Leontius is as follows:

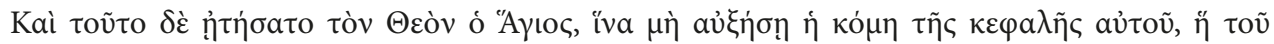

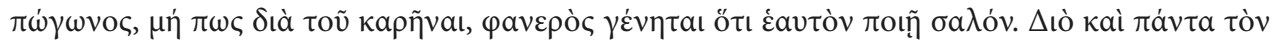

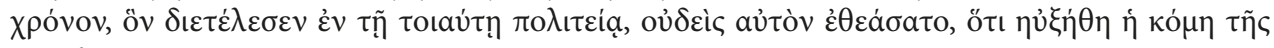

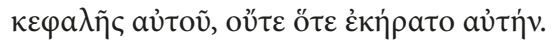

"Also, the saint begged God that neither the hair on his head nor his beard should grow, lest in his having it cut, it become known that he was (only) playing the fool. Therefore, during all the time when he was continuing to behave this way, no one saw the hair on his head grow or saw him cut it" (Rydén 1963, 166).

Therefore, the scarce characterization of Ramon lo Foll coincides exactly with some of the most representative traits of Symeon the Fool. Both show the same signs of their contempt towards social rituals: shaven head and leading a dead dog - acts usual only in people suffering from insanity, be it real or simulated, $-{ }^{15}$ and the same affection for a dissolute life, as it is usually attributed to Symeon (McGuckin 2005, 282). The addition of the sparrowhawk constitutes a motif taken from the corteous culture, as an innovation provided by our author, and of course without any relation to the literary tradition, either Classical or Christian. As a whole, the behavior of Ramon lo Foll imitates the main traits of a holy fool: closeness to as well as distance from power, a provocative look and proneness to an indirect way of arguing, based on analogy and parable.

\section{Some other parallels between the Byzantine hagiography and the life and literary work of Ramon Llull}

All the above-mentioned suggestions do not exhaust the theme of the relationship between our author and the Eastern religious tradition. The identification of new examples of this relationship becomes now a matter of research that involves long-term work. If we just concentrate this research on Blaquerna, it must be reminded that the novel is quite long, that its content does not follow a linear development, and that its form combines different literary genres. Therefore, it would not be surprising that the author has chosen a multifaceted model, including literary traditions not current in his time.

Actually, there are striking parallels between the Byzantine hagiography and the life and the literary work of Ramon Llull. If we concentrate on the life of Saint Andrew the Fool, we can point out some interesting features shared with Llull. Both of them experienced visions that changed their lives: Andrew saw the Holy Virgin, Ramon saw

15 Alfeyev underlines as the main features of the saint his opposition to the earthly power and the abjuration of any material wealth (Alfeyev, 2000; see also Rydén, 1970). 
Jesus Christ in Crucifixion. Something of extreme importance regarding both visions must be underlined: Andrew had his vision in the Church of Blachernae, at Constantinople. In Blaquerna, the name of its protagonist, i. e. the Pope Blaquerna, definitely refers to the Virgin of Blachernae, the Theotokos whose cult was to a noteworthy extent renewed in the eleventh century (Maguire 2004; Rydén 1974). The fact that Llull chose this name for his protagonist should not be taken apart from the general frame in which the novel was conceived, as Blaquerna is an interesting precedent for the Bildungsroman and intended to serve the interest of its author in the ideal of spiritual restoration. The second striking parallel deals with the former non-spiritual life of both characters, since they were involved in a secular milieu that both rejected in order to become servants of the Lord.

In spite of the lack of a comprehensive study on the Byzantine sources of this novel, ${ }^{16}$ the present research implies that this is a stimulating and fruitful way to give a tenable and satisfactory interpretation to Blaquerna. We can state the influence of Byzantine hagiography on the ideological and literary world of Ramon Llull. His interest in Greek culture could have increased in the following years, since he probably stayed in Cyprus in 1301, as it is shown in our contribution on his New Rhetoric, which follows the Byzantine patterns (Redondo 2008). Obviously, the attention to the Ancient and Byzantine traditions could prove most useful for a deeper understanding of the novel. ${ }^{17}$

\section{References}

Allsion Peers E. (transl.) Blanquerna. A Thirteenth Century Romance. London, Jarrolds, 1926.

Alfeyev H. Saint Simeon, the new Theologian, and the Orthodox Tradition. Oxford, UP, 2000.

Aragüés Aldaz J. Ramon Llull y la literatura ejemplar. Alacant, Universitat d'Alacant, 2016.

Badia L. Teoria i pràctica de la literatura en Ramon Llull. Barcelona, Quaderns Crema, 1992.

Badia J., Santanach J., Soler A. Style and Genre in the Writings of Llull, in: L. Badia, J. Santanach, A. Soler (eds). Ramon Llull as a Vernacular Writer: Communicating a New Kind of Knowledge. London, Boydell \& Brewer, 2016, 91-161.

Baist G. Zu Blanquerna. Zeitschrift für romanische Philologie 1879, 3, 90-96.

Bausani A. Note sul 'pazzo sacro' nell'Islam. Studi e materiali di storia della religione 1958, 29, 93-107.

Benz E. Heilige Narrheit. Kyrios 1938, 3, 1-55.

Bonner A. Sobre la data de Blaquerna. Estudios Lulianos 1986, 26, 143-147.

Bonllavi J. (ed.) Blanquerna: qui tracta de sinch estaments de persones $<\ldots>$ per Ramon Lull. València, Johan Joffre, 1521.

Brown P. Eastern and Western Christendom in Late Antiquity: A Parting of the Ways, in: Id. Society and the Holy in Late Antiquity. Berkeley, Univ. of California Press 1982, 179-188 (= Studies in Church History 1976, 13, 1-24).

Brummer R. Zur Datierung von Ramon Llulls Libre de Blaquerna, in: H. Heintze, E. Silzer (Hgg.) Im Dienste der Sprache. Festschrift Viktor Klemperer. Halle, Max Niemeyer, 1958, 98-117 (= Estudios Lulianos $1957,1,257-261$, in a shortened version).

Brummer R. Sobre les fonts literàries del Blanquerna de Ramon Llull. Iberoromania 1979, 9, 1-11.

Brummer R. La importància de la novel la Blanquerna de Ramon Llull en les literatures europees de l'Edat Mitjana. Randa 1986, 19, 137-141.

16 The sheer volume of the novel makes it impossible to give here anything more than some indications about the subject. For instance, the name of one of the main characters, Nastàsia, seems to belong to the Orthodox tradition rather than to the Western one. The characters' names sometimes recall those of a chivalric romance, since they are not Catalan, but drawn from exotic place names or borrowed from other languages (Badia, Santanach, Soler 2016, 105).

17 The temporal and spatial indeterminacy of the story and the exemplary nature of its protagonists mean that the reforms they promote have a universal quality. 
Cameron A. Le silence de l'Absolu: Folles et Fous de Dieu. Recherches de science religieuse 1979, 67, 540-565. Challys N., Dewey H. Byzantine Models for Russia's Literature of Divine Folly (Jurodstvo), in: B. Stolz (ed.) Papers in Slavic Philology I. In Honor of James Ferrell, Ann Arbor, Michigan Slavic Publications, 1977, $36-48$.

Cramer von Bessel H.H. Qui est l'Emperador' du Blanquerna? Bolletí de la Societat Arqueològica Lulliana $1935,26,169-179$.

Dols M.W. Insanity and Its Treatment in Medieval Islamic Society? Medical History. 31, 1987, 1-14.

Dols M. W. Majnun: The Madman in Medieval Islamic Society. Oxford, OUP, 1992.

Downing F. G. Cynic and Christian Origins. Edinburgh, T\&T Clark, 1982.

Feuerstein G. Holy Madness: The Shock Tactics and Radical Teachings of Crazy-Wise Adepts, Holy Fools and Rascal Gurus. New York, Paragon House, 1991.

Friedlein R. El diàleg en Ramon Llull: lexpressió literària com a estratègia apologètica. Barcelona, Universitat de Barcelona, 2011.

Fuertes F.J. Simeón el loco: los rasgos demoníacos de un monje aparentemente extraño. Collectanea Christiana Orientalia 2012, 9, 81-103.

Gallofré M. J. Ramon Llull. Llibre d'Evast e Blanquerna. Barcelona, Editorial 62, 1982.

Galmés S., A. Caimari, R. Guilleumas (eds). Libre d'Evast e Blanquerna I-IV. Barcelona, Barcino, 1935-1954.

Garcías Palou S. El Liber de quinque sapientibus del Bto. Ramón Llull, en sus relaciones con la fecha de composición del Libre de Blaquerna. EL 1957, 1, 377-384.

González Casanovas R. J. Male Bonding as Cultural Construction in Alfonso X, Ramon Llull and Juan Manuel: Homosocial Friendship in Medieval Iberia, in: J.H. Blackmore, G. S. Hutcheson (eds). Queer Iberia: Sexualities, Cultures, and Crossings from the Middle Ages to the Renaissance. Durham, Durham UP, 1992, 157-192.

González Casanovas R., Preaching the Gospel in Barlaam and Blanquerna: Pious Narrative and Parable in Medieval Spain. Viator 1993, 24, 215-231.

Gougaud L. Mulierum consortia. Étude sur le syneisaktisme chez les ascètes celtiques, Uriu 1921, 9, 148-150.

Grau S. Diogenes Laertius between Tradition and Innovation: Philosophers and $\theta \varepsilon \tilde{c}_{0}$ ơ $\alpha \delta \rho \varepsilon \varsigma$, in: R. GarcíaGasco, S. González Sánchez, D. Hernández de la Fuente (eds). The Theodosian Age (A.D.379-455). Oxford, Archaeopress, 2013, 183-189.

Hauptmann P. Die 'Narren um Christ willen' in der Ostkirche. Kirche im Osten 1959, 2, $27-49$.

Hillgarth J.N. Diplomatari lullià. Documents relatius a Ramon Llull i la seva família. Trad. L. Cifuentes. Palma - Barcelona, Universitats de Barcelona i de les Illes Balears, 2001.

Hunt P. Holy Foolishnesh as a Key to Russian Culture, in: P. Hunt, S. Kobets (eds). Holy Foolishness in Russia: New Perspectives, Bloomington, Slavica Publishers, 2011, 1-14.

Ivanov S. A. A Saint in a Whore-house. Byzantinoslavica 1995, 56, 439-445.

Ivanov S. A. La 'santa locura' rusa (iurodstvo, pojabstovo). Erytheia 1999, 20, 75-98.

Ivanov S. A. Holy Fools in Byzantium and Beyond, New York 2006.

Jedrkiewicz S. Sapere e paradosso nell'Antichità: Esopo e la favola. Roma, Dell'Ateneo, 1989, 116-127.

Jedrkiewicz S. The Last Champion of Play Wisdom: Aesop. Itaca. Quaderns Catalans de Cultura Clàssica 1990-1992, 6-8, 115-130.

Kinney D. Heirs of the Dogs: Cynic Selfhood in Medieval and Renaissance Culture, in: R.B.Branham, M.O.Goulet-Caze (eds). The Cynics: The Cynic Movement in Antiquity and Its Legacy. Berkeley, California UP, 1996, 294-328.

Kobets S. The Paradigm of the Hebrew Prophet and the Russian Tradition of Iurodstvo. Canadian Slavonic Papers 50, 2008, 17-32, available at www.slavdom.com (04.10.2017).

Krueger D. Simeon the Holy Fool: Leontios' Life and the Late Antique City. Berkeley, California UP, 1996.

Kurke L. Aesopic Conversations: Popular Tradition, Cultural Dialogue, and the Invention of Greek Prose. Princeton UP, 2001.

Largier N. Diogenes der Kyniker: Exempel, Erzählung, Geschichte in Mittelalter und Früher Neuzeit. Tübingen, Max Niemeyer, 1997.

López Cruces J. L. Diógenes, ciudad sin ley, in: A. Pociña, J. M. García González (eds). En Grecia y Roma V: Hombres notables. Granada, Universidad de Granada, 2015, 177-194.

Luz M. A Description of the Greek Cynic in the Jerusalem Talmud. JSJ 20, 1989, 49-60.

McGuckin J. A Neglected Masterpiece of the Christian Mystical Tradition: the 'Hymns of the Divine Eros' by Simeon the New Theologian. Spiritus Magazine, 2005, 5, 182-202. 
Magdalino P. M. 'What we heard in the Lives of the Saints, we have seen with our own eyes': the Holy Man in Tenth Century Constantinople, in: J. Howards-Johnston, P. A. Howard (eds). The Cult of Saints in Late Antiquity and the Middle Ages. Oxford, OUP, 1999, 83-112.

Maguire H. Byzantine Court Culture from 829 to 1204. Dumbarton Oaks, Harvard UP, 2004.

Mavrommatis L. Byzantine Fools: The Link Between Nature and Society, in: M. Teich, R. Porter, B. Gustafson (eds). Nature and Society in Historical Context. Cambridge, CUP, 1997, 37-50.

Nicol D. Church and Society in the Last Centuries of Byzantium, 1261-1453. Cambridge, CUP, 1979.

Nigg W. Der christliche Narr. Stuttgart — Zürich, Artemis, 1956.

Oliver A. 'Blanquerna' i el 'Llibre de les Bèsties', un retaule de la vida medieval, una utopia de la reforma de l’Església i del món. Setè centenari del llibre de Blaquerna I. Palma 1985, 14-34.

Oliver A. La fecha de la composición del Libre de Blaquerna de Ramon Llull. EL 1959, 3, 325-330.

Pépin J. The Platonic and Christian Ulysses, in: J.O'Meara (ed.), Neoplatonism and Christian Thought. Norfolk, International Society for Neoplatonic Studies, 1982, 3-18.

Pérez L., Miralles J. Nuevos documentos sobre la família de Ramon Llull. Estudios Lulianos 1971, 15, 93-98.

Platzeck W. Das Leben des seligen Raimund Lull. Düsseldorf, Patmos, 1964.

Pope R. W. Fools and Folly in Old Russia. Slavic Review 1980, 39, 476-481.

Redondo J. Sobre les fonts bizantines de la Rhetorica nova de Ramon Llull. Una aproximació a la qüestió, in:

J. Bermúdez et al. (eds). Miscellània en honor a F. Mira. Castelló, Universitat de Castelló, 2008, 297-308.

Reynolds R. Virgines Subintroductae in Celtic Christianity. Harvard Theological Review 1968, 61, 552-563.

Ripoll M. Una lectura no utòpica del Romanç d'Evast e Blanquerna. Lulliana 2012, 52, 3-24.

Rocheau V. Saint Syméon Salos, ermite palestinien et prototype des 'Fous-pour-le-Christ, Proche Orient Chrétien, 1978, 28, 209-219.

Rocheau V. Que savons-nous des Fous-pour-le-Christ? Irénikon 1980, 53, 341-353; 501-512.

Rudi P. O topike zhitij jurodivyh [On the Topics of the Lives of the Holy Fools]. Trudy Otdela drevnerusskoj literatury [Proceedings of the Department of Old Russian Literature] 2007, 58, 443-484.

Rydén L. Bemerkungen zum Leben des heiligen Narren Symeon von Leontius von Neapolis. Uppsala, Almqvist \& Wiksell, 1970.

Rydén L. The Vision of the Virgin at Blachernae and the Feast of Pokrov. Analecta Bollandiana 1974, 94, 63-82.

Rydén L. The Holy Fool, in: S. Hackel (ed.) The Byzantine Saint. Londres, Fellowship of St. Alban and St. Sergius, 1981.

Schleicher W. Ramon Llulls Libre de Evaste Blanquerna: eine Untersuchung über den Einfluss der franziskanichdominikanischen Predigt auf die Prosawerke des katalanischen Dichters. Geneva, Droz, 1958.

Schleicher W. Weiteres zur Datierung von Ramon Lulls Libre de Evast e Blaquerna. Romanische Forschungen 1959, 71, 186-190.

Screech M. A. Ecstasy and the Praise of Folly. London, Duckworth, 1980.

Soler A., Santanach J. (eds). Romanç d'Evast e Blaquerna. Palma, Patronat Ramon Llull, 2009.

Spidlik Th. Fous pour le Christ II: en Orient. Dictionnaire de spiritualité 1964, 5, 752-761.

Swain B. Fools and Folly During the Middle Ages and the Renaissance. New York, Columbia UP, 1932.

Tarré J. Los códices lulianos de la Biblioteca Nacional de París. Analecta Sacra Tarraconensia 1941, 14, 155182.

Tosi P. A. (ed.) Il Novellino. Milano, Tosi, 1825.

Tusquets J. La data de composició del Blaquerna, Boletín de la Real Academia de Buenas Letras de Barcelona 1975-1976, 36, 115-123.

Van Esbroek V. Les saints fous de Dieu, in: M. Aitallah (ed.) Le monachisme syriaque du VIIème siècle à nos jours I, Antelias, Centre d'Études et de Recherches Orientales, 1999, 131-138.

Vandenbroucke F. Fous pour le Christ II: en Occident. Dictionnaire de spiritualité 1964, 5, 761-770.

Vossler K. Poesie der Einsamkeit im Spanien. München, Beck, ${ }^{2} 1950$.

Zeitz H. Die Fragmente des Äsopromans in Papyrushandschriften. Giessen, Noske, 1935.

For citation: Redondo J. An Eastern Tradition in Lullian Blaquerna: the Holy Fool Ramon Lo Foll. Philologia Classica 2017, 12(2), 206-217. https://doi.org/10.21638/11701/spbu20.2017.209 
ВОСТОЧНАЯ ТРАДИЦИЯ В РОМАНЕ РАМОНА ЛЬЮЛА «ВЛАХЕРНА»:

СВЯТОЙ ЮРОДИВЫЙ РАМОН ЛО ФОЛЬ

Джорди Редондо

В статье анализируется отрывок из романа «Влахерна», написанного Рамоном Льюлом около 1276-1283 гг. До настоящего времени не было исследования, которое позволило бы выявить его литературные источники. Сравнительное изучение показывает, каким образом автор обращается с темой, известной и в античной языческой, и в византийской христианской традиции. Античная традиция в основном опирается на образ философа (киника), объединенный с фигурой Эзопа. В Средние века тема оформляется при помощи сюжетных и стилистических элементов, заимствованных из христианской литературы. Что касается ближайших доступных Льюлу источников, то наиболее вероятным автору статьи представляется «Жизнь Симеона» Леонтия Кипрского - произведение, весьма важное с точки зрения распространения литературного типажа, который представлен в рассматриваемом тексте.

Ключевые слова: Рамон Льюл, византийская традиция, юродство и святость, кинизм.

Received: 09.07.2017

Final version received: 14.10.2017 